\title{
LETTERS
}

\section{Who Gets Testosterone?}

\author{
Jeffrey L. Jackson, MD MPH
}

Zablocki VAMC, Milwaukee, WI, USA

$\mathrm{J}$ Gen Intern Med 32(10): 1074

DOI: $10.1007 / \mathrm{s} 11606-017-4112-0$

(C) Society of General Internal Medicine (outside the USA) 2017

$\mathrm{H}$ ypogonadism in males is common, with a prevalence of symptomatic androgen deficiency of $5-12 \%$ in males between 40 and 70 years of age. ${ }^{1},{ }^{2}$ Jasuja and colleagues explored the pattern of testosterone prescribing using VA administrative data, linking prescription fills to ICD-9 codes ${ }^{1}$. In previous work, this group demonstrated that $16 \%$ of VA veterans are prescribed testosterone without undergoing the recommended workup ${ }^{2}$. In this study, they found that only $6 \%$ of men had a diagnosis that would justify receiving testosterone treatment. They conclude that $94 \%$ of testosterone receipts in the VA are off-label purposes ${ }^{3}$. If this were true, it would be disturbing. It would also fly in the face of most measures demonstrating that the VA matches or exceeds care quality indicators compared to non-VA settings and would contradict the groups own previous work, in which $84 \%$ of veterans given testosterone had an appropriate workup prior to testosterone initiation ${ }^{4}$.

The explanation for this discrepancy is likely the use of ICD-9 codes. In non-VA settings, the accuracy of ICD-9 coding has been demonstrated to be reasonable, largely because of the link between coding and insurance reimbursement for services. However, there is no such incentive in the VA. Except when ordering nonformulary medications, in which the VA pharmacy may require the problem to be added to the problem list before they will fill the prescription, there is no linkage and no incentive for VA providers to make sure their diagnostic codes are accurate. This problem is likely to be worsened by the recent roll-out of ICD-10, given the lack of support to providers in the VA's adoption of this upgraded coding system. As an aside, I reviewed my own clinical practice and found that seven of my veterans are currently on testosterone. All have symptomatic hypogonadism with a pre-treatment low testosterone. All have had subsequent serum testosterone assessments and report improvement in their symptoms. These seven are a minority as most of my veterans have decided to stop testosterone replacement when they experienced no clinical improvement despite a rise in serum testosterone levels. Review of my ICD-9 coding for these veterans found that only one had an ICD-9 code for hypogonadism. I suspect my practice is not atypical and is unfortunate for researchers hoping to use VA ICD coding to describe provider practice.

Corresponding Author: Jeffrey L. Jackson, MD MPH; Zablocki VAMC, Milwaukee, WI, USA (e-mail: Jeffrey.Jackson6@va.gov).

\section{Compliance with Ethical Standards:}

Potential Conflict of Interest: The author is the GIM section chief at the Zablocki VA and is a VA primary care physician.

\section{REFERENCES}

1. Harman SM, Metter EJ, Tobin JD, Pearson J, Blackman MR. Longitudinal effects of aging on serum total and free testosterone levels in healthy men. Baltimore Longitudinal Study of Aging. J Clin Endocrinol Metab. 2001:86(2):724-31.

2. Travison TG, Araujo AB, O'Donnell AB, Kupelian V, McKinlay JB. A population-level decline in serum testosterone levels in American men. J Clin Endocrinol Metab. 2007;92(1):196-202

3. Jasuja GK, Bhasin S, Reisman JI, Hanlon JT, Miller DR, Morreale AP, Pogach LM, Cunningham FE, Park A, Berlowitz DR, Rose AJ. Who gets testosterone? Patient characteristics associated with testosterone prescribing in the veteran affairs system: a cross-sectional study. J Gen Intern Med. doi: 10.1007/s11606-016-3940-7

4. Jasuja GK, Bhasin S, Reisman JI, Berlowitz DR, Rose AJ. Ascertainment of testosterone prescribing practices in the VA. Med Care. 2015;53(9):746-52. 